\title{
The role of coral colony health state in the recovery of lesions
}

Claudia P Ruiz-Diaz, Carlos Toledo-Hernandez, Alex E. Mercado-Molina, María-Eglée Pérez, Alberto M Sabat

The coral disease literature has focused, for the most part, on the etiology of the more than 35 coral afflictions currently described. Much less understood are the factors that underpin the capacity of corals to regenerate lesions, including the role of colony health. This lack of knowledge with respect to the factors that influence tissue regeneration significantly limits our understanding of the impact of diseases at the colony, population, and community level. In this study, we experimentally compared tissue regeneration capacity of diseased versus healthy fragments of Gorgonia ventalina colonies at $5 \mathrm{~m}$ and $12 \mathrm{~m}$ of depth. We found that the initial health state of colonies (i.e., diseased or healthy) had a significant effect on tissue regeneration (healing). All healthy fragments exhibited full recovery regardless of depth treatment, while diseased fragments did not. Our results suggest that being diseased or healthy has a significant effect on the capacity of a sea fan colony to repair tissue, but that environmental factors associated with changes in depth, such as temperature and light do not. We conclude that disease not just compromise vital functions such as growth and reproduction, in corals but also compromise their capacity to regenerate tissue and heal lesions. 
2 Claudia Patricia Ruiz-Diaz*1,2

31 Department of Environmental Sciences, University of Puerto Rico, PO Box 70377 Río Piedras

4 P.R.

5 Phone: 1-787-764-0000 ext. 2713

62 Sociedad Ambiente Marino SAM, PO Box 22158, San Juan Puerto Rico 00931,

7 email: claudiapatriciaruiz@gmail.com,*corresponding author

8 Carlos Toledo-Hernández ${ }^{2}$

92 Sociedad Ambiente Marino SAM, PO Box 22158, San Juan Puerto Rico 00931

10 email: c_toledo_hernandez@yahoo.com

11 Alex E. Mercado-Molina ${ }^{2,3}$

122 Sociedad Ambiente Marino SAM, PO Box 22158, San Juan Puerto Rico 00931

133 Department of Biology, University of Puerto Rico, PO Box 23360 Río Piedras P.R.

14 email:amolinapr@gmail.com

15 María Eglee Perez ${ }^{4}$

164 Department of Mathematics, University of Puerto Rico, PO Box 70377 Río Piedras P.R.

17 email: maria.perez34@upr.edu

18 Alberto M. Sabat ${ }^{3}$

193 Department of Biology, University of Puerto Rico, PO Box 23360 Río Piedras P.R.

20 email: amsabat@gmail.com

\section{ABSTRACT}

22 The coral disease literature has focused, for the most part, on the etiology of the more than 35

23 coral afflictions currently described. Much less understood are the factors that underpin the

24 capacity of corals to regenerate lesions, including the role of colony health. This lack of

25 knowledge with respect to the factors that influence tissue regeneration significantly limits our

26 understanding of the impact of diseases at the colony, population, and community level. In this

27 study, we experimentally compared tissue regeneration capacity of diseased versus healthy

28 fragments of Gorgonia ventalina colonies at $5 \mathrm{~m}$ and $12 \mathrm{~m}$ of depth. We found that the initial

29 health state of colonies (i.e., diseased or healthy) had a significant effect on tissue regeneration

30 (healing). All healthy fragments exhibited full recovery regardless of depth treatment, while

31 diseased fragments did not. Our results suggest that being diseased or healthy has a significant

32 effect on the capacity of a sea fan colony to repair tissue, but that environmental factors 
33 associated with changes in depth, such as temperature and light do not. We conclude that disease

34 not just compromise vital functions such as growth and reproduction, in corals but also

35 compromise their capacity to regenerate tissue and heal lesions.

\section{INTRODUCTION}

Most of the present-day coral reef habitats no longer exhibit the complex community structure that was commonly observed several decades ago. This is particularly evident in the Caribbean where the most important reef species such as the coral-building Caribbean Acropora palmata, A. cervicornis and the Orbicella complex (formerly Montastraea), and the predatory reef fish and herbivores such as the black sea urchins and sea fan corals, have dramatically decreased in abundance (Kim \& Harvell, 2002). These losses have not just changed the seascape of the reefs, but have also caused important ecological alterations to coral survival, growth and reproductive schedules at local and regional scales (Sutherland et al., 2004; Hoegh-Guldberg et al., 2007; Weil et al., 2009; Burns and Takabayashi, 2011; Ruiz-Diaz et al., 2013).

Of the myriad of stressors affecting the viability of corals, disease is currently ranked at the top of the list. Coral diseases are typically diagnosed based on changes in the normal coloration of corals and by the appearance of lesions (partial tissue mortality). Under severe circumstances, such as when a pathogen is highly virulent or the coral host is immune-suppressed, diseaseinduced lesions can increase in size quickly killing the colony. However, given a strong immune response, diseased-induced wounds can be contained and either persist for a prolong period (if the colony is able to contain the disease but not regenerate new tissue) or temporary (if the colony is able to regenerate tissue over the whole lesion) (Ruiz-Diaz et al., 2013).

Several studies have identified wound characteristic as a major factor affecting the rate at which a colony can regenerate new tissue and eliminate a lesion. For instance, several studies agree that regeneration rate decreases with an increase in lesion size (Bak \& Steward-Van, 1980; Oren et al., 1992; Kramrsky-Winter \& Loya, 2000). Other studies suggest that the area/perimeter ratio of a lesion largely governs the rate of wound healing process (Lirman, 2000). Whereas other, suggest that wound position within the colony i.e., lesions at the edge of the colony vs. lesion at the center of the colony, determine the wound healing process (Meester et al., 1992). 
61 Many researchers have also linked the ongoing environmental degradation experienced by most

62 coral reefs with the advent of coral diseases, which currently is one of the main sources of lesions 63 on corals. For instance, in a study by Toledo-Hernández et al. (2007), the capacity of corals to 64 recover from diseases (i.e., lesion recovery) was correlated with turbidity and/or sedimentation.

65 Corals in areas with high turbidity and sedimentation had higher frequencies of disease-induced 66 lesions and larger lesions compared to corals in less degraded habitats. Higher water temperature 67 has been linked to the progression of lesions caused by black band disease, which affects several 68 coral species in the Caribbean and the Great Barrier Reef (Kuta \& Richardson 2002; Haapkylä et al., 2011). Similarly, nutrient enrichment increased the severity of aspergillosis of Gorgonia ventalina and yellow band disease on Orbicella annularis and O. franksi (Bruno et al., 2003). Muller \& Woesi (2009) showed that white-plague lesion significantly decreased on Corpophyllia natans shaded from solar radiation when compared to $C$. natans without shading. Although results from these studies have been useful in advancing our understanding of the healing process on corals, we still lack comprehensive knowledge of how other factors such as the health state of a colony baring lesion, affect the healing process. However, progress has been made. For instance, Fine et al., (2002) working with bleached scleractinian corals and Ruiz-Diaz et al (in press), working with diseased gorgonians, have shown that diseased corals regenerate man-made lesions slower than man-made lesion inflicted on healthy looking corals. Initiatives to mitigate the effects of coral disease lack information about factors affecting the recovery of corals from disease-induced lesions. While we do have some understanding about the factors that make a coral vulnerable to disease i.e., abnormally high temperature and sedimentation among others, we lack understanding regarding how the health condition of the coral affects its recovery. The objective of this study is to experimentally test if the health state and variability in environmental factors correlated with depth, significantly influence lesion regeneration on the sea fan G. ventalina. To do this, we established eight nursery lines at two depths within the same reef (four nursery lines per depth, $5 \mathrm{~m}$ and $12 \mathrm{~m}$ ). Each nursery line consisted of four fragments from two healthy and two diseased G. ventalina colonies. We scraped tissue to some of the healthy fragments and scraped the diseased area of the diseased fragments and followed their recovery through time. Concomitantly, we measured the temperature and light intensity at both depths ( $5 \mathrm{~m}$ and $12 \mathrm{~m})$ to document differences in these factors between depths.

91 We hypothesized that fragments from healthy colonies would regenerate new tissue at a faster 92 rate than those from diseased colonies because, at the start of the experiment, diseased colonies 
93 are expected to have an activated immune response and thus fewer resources to allocate to tissue

94 regeneration than healthy ones. We also reasoned that, independent of health state, tissue

95 recovery rate at $12 \mathrm{~m}$ would be slower than at $5 \mathrm{~m}$ due to reduced light availability.

\section{METHODS}

\section{Study site}

98 The experiment was conducted in Cayo Largo reef (CL) from April to August 2013. CL is located

$996.5 \mathrm{~km}$ off the northeastern coast of Puerto Rico (N $18^{\circ} 19.09^{\prime} 42^{\prime \prime}$ W $\left.65^{\circ} 35.01^{\prime} 75^{\prime \prime}\right)$. CL is a

100 patch reef with a coral assemblage dominated by large colonies of Gorgonia ventalina,

101 Pseudopterogorgia acerosa and small colonies of the Orbicella annularis, Acropora palmata and

102 Porites astreoides (for further description of the study area see Hernández-Delgado, 2006). The

103 tissue samples were collected under permit 2012-IC-086 issued to Claudia P. Ruiz Diaz,

104 University of Puerto Rico (UPR) Rio Piedras campus, given by the Puerto Rico Department of

105 Natural Resources, Commonwealth of Puerto Rico.

\section{Experimental design}

\section{Nursery lines}

108 A total of eight nursery lines each of $2.7 \mathrm{~m}$ in length and $1 \mathrm{~m}$ above the bottom, were established at

109 two depths, $5 \mathrm{~m}$ and $12 \mathrm{~m}$ (hereafter shallow and deep zones, respectively) at CL (Fig. 1). Four of

110 these nursery lines were established at the shallow zone and the remaining four at the deep zone.

111 To setup the nursery lines, we collected tissue fragments from 16 sea fan colonies (fragment

112 donor colonies) inhabiting an area of about $800 \mathrm{~m}^{2}$ and at depths between $1-1.5 \mathrm{~m}$. Given that sea

113 fans do not exhibit asexual reproduction, selected colonies are assumed to be genetically distinct

114 from each other. Eight of the fragment donor colonies were diagnosed as healthy i.e., fans

115 showing no visual sign of disease or tissue purpling; whereas the remaining eight donor colonies

116 were diagnose as diseased i.e., fans showing an area colonized by fouling organisms, mainly

117 algae, with a purple tissue ring surrounding the over grown (Fig. 2). Once collected, each health

118 fragment was split in two identical halves of approximately $165.5 \mathrm{~cm}^{2}$, one of which was placed

119 on a shallow nursery line and the other on a deep nursery line. Diseased fragments were split so

120 that the lesion represented approximately $16 \%$ of the total surface area of each fragment. Once 
121 split, one half-fragment from the same donor colony was placed at a shallow nursery lines and the

122 other half at a deep nursery line. Once fully assembled, each nursery line consisted of four colony

123 fragments (two healthy and two diseased) separated by $30 \mathrm{~cm}$ each (Fig.1). Notice that, no two

124 fragments from the same colony were placed in the same nursery line nor at the same depth.

\section{Tissue scraping}

126 Tissue scraping was performed to measure the capacity of fragments to regenerate tissue under

127 contrasting health states and environmental conditions. We scraped tissue from one of the healthy

128 and diseased fragments per nursery line, per depth (hereafter HFS and DFS, respectively) (Fig.

129 1). In the case of HFS fragments, the equivalent of ten percent of the total surface area was

130 scraped from the center of the fragment. For DFS fragments, the total injured area (the area

131 overgrown by fouling organisms plus the purpled tissue) was scraped. Scraping was performed

132 using a metal bristle brush and resulted in the exposure of the axial skeleton in both cases. The

133 remaining healthy and diseased fragments, (hereafter HF and DF respectively), were not

134 subjected to any tissue scraping (Fig. 1). HF fragments were used as sentinels. Tissue mortality in

135 these fragments would signal either an adverse effect of fragmentation or too harsh

136 environmental conditions both of which would invalidate the experiment. HFS and DFS

137 fragments were included to address the main objective of the study, which is to test the effect of

138 health state on tissue generation. DF are disease fragments with filamentous algae or other

139 fouling growing in the expose skeleton. They were added to the experiment to measure the

140 "natural" regeneration rate of tissue growing over skeleton covered by fouling organisms or/and

141 pathogen(s).

\section{Tissue regeneration estimates}

143 To document the progression of the wound-healing process, close-up pictures of each fragment

144 were taken every two weeks between April and August 2013 or until lesions healed completely.

145 Lesions were deemed healed (fully recovered), if the bare skeleton was completely covered by

146 healthy tissue. The percent area of the lesion that did recovered at the end of the experiment was

147 estimated by subtracting the area without soft tissue measured at the end of the experiment to the

148 area (bared axial skeleton) measured at the beginning of the experiment, just after scraping the

149 lesion. Image analysis software (Sigma Scan Pro Image Analysis version 5.0 Software) was used 
150 to measure all individual and clone fragments pictures. These measurements were validated using

151 in situ measurements.

\section{Environmental variables}

153 To quantitatively determine if environmental conditions differed at each depth (5m and $12 \mathrm{~m})$, we

154 measured the water temperature and light intensity. Temperature and light were measured using

155 one Hobo Pendant temperature/light data logger 64k-UA-002-64 (Onset Company) at each depth.

156 Data loggers were secured in place using metal rods and a zip tie. Temperature measurements

157 were recorded every 15 minutes for 14 days from April 26 to May 3, May 16 to June 7, June 28

158 to July 12, and August 9 to August 23, 2013. Light intensity data was obtained only during the

159 first 10 days after the loggers were placed as seaweeds typically colonize the logger and affect the 160 readings (personal observations).

\section{Statistical analysis}

162 Lesion recovery was expressed as the rate at which tissue regenerated (in $\left.\mathrm{cm}^{2}\right)$ through time. This

163 can be represented as the slope of a linear regression with time (in days) in the x-axis and lesion

164 area in the y-axis (log transformed) (Meester et al., 1992). To determine whether depth (5m and

$16512 \mathrm{~m}$ ) and fragment treatments (DF DFS, and HFS) had an effect on the tissue regeneration

166 through time, the slope of each fragment was analyzed using a repeated measure ANOVA, as

167 fragments from the same colony (placed at the shallow and deep nursery lines) are not

168 independent from each other. Statistical analyses were performed using R version 3.1 (R Core

169 Team, 2014).

\section{RESULTS}

\section{Environmental variables and recovery}

172 Light intensity and temperature showed statistical differences between depths (see Table 1).

173 Average temperature at $5 \mathrm{~m}$ was $28.555 \pm 0.012^{\circ} \mathrm{C}($ mean $\pm \mathrm{SE})$, while at $12 \mathrm{~m}$ it was $28.334 \pm$

$1740.006^{\circ} \mathrm{C}$. Average light intensity at $5 \mathrm{~m}$ was $11203.55 \pm 459.410 \mathrm{Lux}$; while at $12 \mathrm{~m}$ it was

$175 \quad 3429.36 \pm 129.11$ Lux.

\section{Tissue Recovery}


177 All the healthy sentinel fragments (HF) survived the experiment without any necrosis; in fact,

178 they increasing in size at both depths. The results from the repeated measure ANOVA analysis

179 performed showed that tissue recovery was only affected by fragment's health state $\left(\mathrm{F}_{2,15}=5.477\right.$,

$180 p=0.0317)$. Depth $\left(\mathrm{F}_{1,15}=3.587, p=0.095\right)$ and the interaction between depth and health state

181 showed no significant differences $\left(\mathrm{F}_{5,15}=3.915, p=0.065\right.$; Fig. 3B). The results of the Tukey HSD

182 analysis showed significant differences between DFS and HFS (diff $=0.020, p=0.001$ ) and DFS

183 and DF (diff $=0.015, p=0.016)$.

\section{DISCUSSION}

185 Coral colonies are very vulnerable to tissue loss due to predation, pathogens, and abrasion,

186 among others. Failure to regenerate lost tissue could impair their survivorship by allowing

187 potentially harmful organisms to settle in the exposed skeleton, further infecting healthy areas of

188 the corals. Repair failure could also affect other vital function of corals such the heterotrophic

189 feeding and ultimately growth, in addition to reproduction, as loss of polyps will negatively affect

190 such activities. Thus, tissue regeneration should be of utmost importance in order for coral

191 colonies to reduce the risk of diseases, improving their survivorship, competitive capacity and

192 ultimately reproduction and somatic growth.

193 Numerous researchers have studied the link between environmental factors, and the frequency

194 and severity of coral diseases. In fact, some of these studies have argued that as climate change

195 continues to exacerbate, so will be the physiological stress associated with it, and consequently,

196 the frequency and severity of coral disease will also increase (Kuta \& Richarson, 2002;

197 Haapkylä et al., 2011; Croquer et al., 2006; William et al., 2014). In comparison, studies

198 addressing how the health state of corals affects the coral's capacity to repair are by far less

199 common (however see Mascarelli \& Bunkley-Williams, (1999); Fine et al., 2002; Ruiz-Diaz et

200 al., in Press). This study is an attempt to address this knowledge gap by documenting the

201 relationship between the recovery dynamics of healthy and diseased coral colonies and

202 environmental factors such as temperature, light intensity while controlling for genetic variability. 
204 This study shows that the health state of colonies (i.e., being diseased or healthy) has a significant

205 effect on the tissue repair capacity of sea fans. All healthy fragments, regardless of the depth

206 where they were placed (thus regardless of temperature and light regimes), exhibited full

207 recovery whereas diseased fragments did not. Furthermore, scraped healthy fragments healed

208 faster than scraped diseased fragments (i.e., on average 78 days vs. 97 days, respectively). It is

209 possible that genetic differences among colonies, that may have lead to different levels of susceptibility to

210 disease in the first place, might have lead to the observed differences in healing rate. However, another

211 result is that unscraped diseased fragments (DF) healed at a significantly slower rate than scraped

212 ones (DFS) supports that tissue with lesion cannot heal as fast as tissue without a lesion even if they

213 come from the same colony. In other words, growing tissue over a skeleton covered with fouling

214 organisms is a slower process because it is more costly, as the coral is competing for space and

215 also allocating resources into tissue regeneration. By contrast, scraped fragments can allocate

216 resources into tissue regeneration.

217 The results of the experiment agree with our initial hypothesis, which stated that the health state

218 does affect the capacity of fragments to recover. In fact our results show that being diseased

219 negatively affect the capacity of fragments to recover. These results also concur with several

220 authors that have argued that the diseased condition negatively affect the tissue regeneration

221 capacity of corals. For instance, Mascarelli \& Bunkley-Williams, (1999) compared the rates of

222 tissue regeneration of Orbicela annularis corals under contrasting health conditions (healthy and

223 artificially bleached fragments) and reported that healthy ramets did not just heal completely but

224 they also recovered faster than diseased ones. By contrast, two of the bleached ramets died, and

225 the remaining fragments did not exhibit full recovery. Likewise, Ruiz-Diaz et al., (in Press)

226 scraped naturally occurring lesions from sea fan colonies and as control, scraped the equivalent of

$22710 \%$ of the surface area of healthy sea fan colonies and found that tissue recovery was

228 significantly slower in diseased fans when compared to healthy fans. A plausible explanation for

229 these differences is that diseased colonies have fewer resources to invest into tissue repair as their

230 resources were already compromised by the immune response prior to scraping (Nagelkerken et

231 al., 1997). Further evidence in support of this explanation of resource limitation would have been

232 obtained by contrasting regeneration rates of healthy fragments from diseased colonies with that

233 of diseased and healthy fragments from healthy colonies; we, however, did not included healthy

234 fragments from diseased colonies in our experimental design. Corals, like all living organisms,

235 have finite resources to allocate into several vital functions such as growth, reproduction, immune 
236 defense or lesion regeneration. Given these resource constraints, the allocation of resources into

237 certain vital functions, such as immune defense, means that fewer resources could be available

238 for lesion regeneration (Oren et al., 2001). Several studies conducted on a variety of corals

239 support this hypothesis. For instance, Petes et al., (2003) working on sea fan coral G. ventalina

240 reported reproductive suppression in diseased colonies, presumably due to a shift in resource

241 allocation from reproduction to immunity. Similarly, Palmer et al., (2010) suggest that Porites sp.

242 invests considerably more resources into immune constituents such as melanin biosynthesis than

243 A. millepora. This investment of resources into immunity provides Porites with a higher disease

244 and bleaching resistance. By contrast, A. millepora invests more resources into growth compared

245 to Porites, although at a cost in reduced immunity, as acroporids are among the corals most

246 susceptible to bleaching and disease.

247 Effect of depth on lesion recovery

248 One of the main concerns of the scientific community is that changes in environmental conditions

249 could induce physiological stress on corals (Alker et al., 2004). These stresses could impair vital

250 life history traits such as grow, reproduction or even the capacity of corals to recover after a

251 disturbance. In our study, however, environmental factors associated with changes in depth,

252 showed no evident effects on the capacity of sea fan fragments to regenerate tissue, even though,

253 the parameters measured were statistically different between depths. Our failure to detect depth

254 effects could have several explanations, not necessarily mutually exclusive. For instance, it could

255 be possible that the difference in environmental factors recorded between $5 \mathrm{~m}$ and $12 \mathrm{~m}$ were not

256 sufficient to induce physiological stresses on the fragments, thereby not precluding their capacity

257 to regenerate tissue. Alternatively, it could be that, there was a depth effect, but was manifested

258 on other life history trait such as reproduction or somatic growth, in which case, we were not able

259 to detect it. It is also plausible to argue that sea fans are rather tolerant to changes in

260 environmental conditions. Indeed, Ruiz-Diaz et al., (in Press) found no differences in tissue

261 recovery of in $G$. ventalina inhabiting reefs with contrasting water quality.

\section{Conclusions}

263 Diseases of corals not just compromise vital functions such as growth and reproduction, but also

264 compromise their recovery capacity. Arguably, resources invested against pathogens could also

265 be the same driving the tissue repair as stated by limited budget theory proposed by Oren et al., 
266 2001. In that regard, these vital functions may be competing for resources. This raises questions

267 regarding the sharing of resources and resource depletion. For instance, in the eventuality of two

268 simultaneous but different immunological insults, how corals should prioritize its resources to

269 respond to both events? How intense should be a disturbance in order to induce immune

270 responses that affect several life history traits? It that regard, it could be possible that the

271 environmental conditions in this study may have indeed caused stress on the sea fan fragments,

272 but these stresses were manifested in other vital functions such as reproduction or rate growth,

273 which they were not studied in this work. Our study also shows that sea fans are very robust

274 corals that can tolerate variable environmental conditions. In this regard, this may explain why

275 this species thrives relatively well in many coral reefs across Puerto Rico regardless of

276 environmental degradation.

277 Acknowledgments

278 Ruber Rodríguez and Francisco J. Soto for field assistance. Paul Furumo, Molly Ramsey and

279 Cheryl Woodley for his critical review.

References

281

282

283

284

285

286

287

288

289

290

291

292

293

294

295

296
Alemu IJB, Clement Y. 2014. Mass Coral Bleaching in 2010 in the Southern Caribbean. PLOS ONE 9(1): e83829. doi:10.1371/journal.pone.0083829

Alker AP, Kim K, Dube DH, Harvell CD. 2004. Localized induction of a generalized response against multiple biotic agents in Caribbean sea fans. Coral Reefs 23:397-405

Andras, J P, Rypien KL, Harvell C D. 2013. Range-wide population genetic structure of the Caribbean sea fan coral, Gorgonia ventalina. Molecular Ecology, 22(1), 56-73. doi:10.1111/mec.12104

Bak RPM, Steward-Van YS. 1980. Regeneration of superficial damage in the scleractinian corals Agaricia agaricites F. Purpurea and Porites astreoides. Bulletin of Marine Science 30:883-887.

Bruno JF, Petes LE, Harvell CD, Hettinger A. 2003. Nutrient enrichment can increase the severity of coral diseases. Ecology Letters 6:1056-1061. doi:10.1046/j.14610248.2003.00544.x

Bruno JF, Selig ER, Casey KS, Page CA, Willis BL, Harvell CD, Hugh S, Melendy AM. 2007. Thermal Stress and Coral Cover as Drivers of Coral Disease Outbreaks. PLOS BIOLOGY 5(6): e124. 
297

298

299

300

301

302

303

304

305

306

307

308

309

310

311

312

313

314

315

316

317

318

319

320

321

322

323

324

325

326

327

328

329

330

331

332

333

334

335

336

337

Bruno JF, Stepen EP, Ivana Kim K. 2011. Impacts of aspergillosis on sea fan coral demography: modeling a moving target. Ecological Monographs 81:123-139.

Burns JHR, Takabayashi M. 2011. Histopathology of growth anomaly affecting the coral, Montipora capitata: implications on biological functions and population viability. PlOS ONE 6:e28854.

Cróquer A, Bastidas C, Lipscomp D, Rodríguez-Martínez RE, Jordan-Dahlgren E, Guzman HM. 2006. First report of folliculinid ciliates affecting Caribbean scleractinian corals. Coral Reefs 25:187-191.

Davy SK, Allemand D, Weis VM. 2012. Cell biology of cnidarian-dinoflagellate symbiosis. Microbiology and molecular biology reviews 76:229-61.

Fine M, Oren U, Loya Y. 2002. Bleaching effect on regeneration and resource translocation in the coral Oculina patogonica. Marine Ecology Progress Series 234:119-125.

Finelli C, Helmuth B, Pentcheff N, Wethey D. 2007. Intracolony variability in photosynthesis by corals is affected by water flow: role of oxygen flux. Marine Ecology Progress Series 349:103-110.

Fisher EM, Fauth JE, Hallock P, Woodley CM. 2007. Lesion regeneration rates in reefbuilding corals Montastraea spp . as indicators of colony condition. Marine Ecology Progress Series 339:61-71.

Frade PR, Englebert N, Faria J, Visser PM, Bak RPM. 2008. Distribution and photobiology of Symbiodinium types in different light environments for three colour morphs of the coral Madracis pharensis: is there more to it than total irradiance? Coral Reefs 27:913-925.

Haapkylä J, Unsworth RKF, Flavell M, BourneDG, SchaffelkeB, Willis BL. 2011. Seasonal rainfall and runoff promote coral disease on an inshore reef. PLOS ONE 6, e16893.

Hernández-Delgado EA, Toledo-Hernández C, Claudio G H, Lassus J, Lucking MA, Fonseca J, Hall K, Rafols J, Horta H, Sabat AM. 2006. Spatial and taxonomic patterns of coral bleaching and mortality in Puerto Rico during year 2005. Satellite Tools and Bleaching Response Workshop: Puerto Rico and the Virgin Islands. St. Croix, U.S. Virgin Islands. $16 \mathrm{pp}$.

Heyward AJ, Collins JD. 1985. Fragmentation in Montipora ramose the genet and ramet concept applied to a reef coral. Coral Reefs 4:35-40.

Hoegh-Guldberg O, Mumby PJ, Hooten AJ, Steneck RS, Greenfield P, Gomez E, Harvell CD, Sale PF, Edwards AJ, Caldeira K, Knowlton N, Eakin CM, Iglesias-Prieto R, Muthiga N, Bradbury RH, Dubi A, Hatziolos ME. 2007. Coral Reefs Under Rapid Climate Change and Ocean Acidification. Science 318:1737-1742.

Iglesias-Prieto R, Trench R. 1994. Acclimation and adaptation to irradiance in symbiotic dinoflagellates. I. Responses of the photosynthetic unit to changes in photon flux density. Marine Ecology Progress Series 113:163-175.

Kim K, Harvell CD. 2002. ASPERGILLOSIS OF SEA FAN CORALS: DISEASE DYNAMICS IN THE FLORIDA KEYS. In: Porter JW, Porter K. (eds) The Everglades, Florida Bay, and coral reefs of the Florida Keys: an ecosystem handbook. CRC Press, Boca Raton, FL, p 813-824. 
338

339

340

341

342

343

344

345

346

347

348

349

350

351

352

353

354

355

356

357

358

359

360

361

362

363

364

365

366

367

368

369

370

371

372

373

374

375

376

377

378

379

Kinzie RA. 1974. Experimental infection of aposymbiotic gorgonian polyps with zooxanthellae. Journal Experimental Marine Biology Ecology 15:335-345.

Kirt JTO. 1994. LINGHT AND PHOTOSYNTHESIS IN AQUATIC ECOSYSTEMS, 2nd edn. Cambridge University Press, Cambridge.

Kramrsky-Winter E, Loya Y. 2000. Tissue regeneration in the coral Fungia granulosa: the effect of extrinsic and intrinsic factors. Marine Biology 137: 867-873.

Kuta KG, Richarson LL. 2002. Ecological aspects of black band disease of corals: relationships between disease incidence and environmental factors. Coral Reef 21:393-398.

Lirman D. 2000. Lesion regeneration in the branching coral Acropora palmata: effects of colonization, colony size, lesion size and lesion shape. Marine Ecology Progress Series 197:209-215.

Mascarelli PE, Bunkley-William L. 1999. An experimental field evaluation of healing in damaged, unbleached and artificially bleached star coral, Montastraea annularis. Bulletin of Marine Science 65:511-586.

Mass T, Genin A, Shavit U, Grinstein M, Tchernov D. 2010. Flow enhances photosynthesis in marine benthic autotrophs by increasing the efflux of oxygen from the organism to the water. Proceedings of the National Academy of Sciences of the United States of America 107:2527-31.

Meesters, EH, Bos A, Gast JG. 1992. Effect of Sedimentation and Lesion Position on Coral Tissue Regeneration. In proceeding of: 7th International Coral Reef Symposium.

Muller EM, Woesik RV. 2009. Shading reduces coral-disease progression. Coral Reef 28:757760.

Muscatine L, Porter JW, Kaplan IR. 1989. Resource partitioning by reef corals as determined from stable isotope composition. Marine Biology 100:185-193.

Nagelkerken I, Buchan, K Smith, G Bonair, K Bush, P Garzon-Ferreira,J, Botero L, Gayle P, Harvell C, Heberer C, Kim K, Petrovic C, Pors L, Yoshioka. 1997. Widespread disease in Caribbean sea fans: II. Patterns of infection and tissue loss. Marine Ecology Progress Series 160:255-263.

Oren U, Benayahu Y, Lubinevsky H, Loya Y. 2001. Colony integration during regeneration in the stony coral Favia Favus. Ecology 82:802-813.

Palmer CV, Bythell JC, Willis BL. 2010. Levels of immunity parameters underpin bleaching and disease susceptibility of reef corals. The FASEB Journal : Official Publication of the Federation of American Societies for Experimental Biology 24:1935-1946. doi:10.1096/fj.09-152447

Petes LE, Harvell CD, Peters EC, Webb MaH, Mullen KM. 2003. Pathogens compromise reproduction and induce melanization in Caribbean sea fans. Marine Ecology Progress Series 264:167-171. doi:10.3354/meps264167

Robison JD, Warner ME. 2006. Differential Impacts of Photoacclimation and Thermal Stress on the Photobiology of Four Different Phylotypes of Symbiodinium (Pyrrhophyta)1. Journal of Phycology 42:568-579.

Ruiz-Diaz CP, Toledo-Hernández C, Sabat A, Marcano M. 2013. Immune response to a pathogen in corals. Journal of theoretical Biology 332:141-148. 
380

381

382

383

384

385

386

387

388

389

390

391

392

393

394

395

396

397

398

399

Ruiz-Diaz CP, Toledo-Hernández, Alex Mercado-Molina C, Sabat A. 2015. Scraping and extirpating: two strategies to induce recovery of diseased sea fans Gorgonia ventalina. Marine Ecology In press.

Sebens K P, Helmuth B, Carrington E, Agius B. 2003. Effects of water flow on growth and energetics of the scleractinian coral Agaricia tenuifolia in Belize. Coral Reef 22:35-47.

Sebens KP, Helmuth B, Carrington E, Agius B. 2003. Effects of water flow on growth and energetics of the scleractinian coral Agaricia tenuifolia in Belize. Coral Reef 22: 35-47.

Sutherland K P, Porter J W, Torres C. 2004. Disease and immunity in Caribbean and IndoPacific zooxanthellate corals. Marine Ecology Progress Series 266:273-302. doi:10.3354/meps 266273

Toledo-Hernández C, Sabat, AM, Zuluaga-Montero A. 2007. Density, size structure and aspergillosis prevalence in Gorgonia ventalina at six localities in Puerto Rico. Marine Biology 152:527-535.

Weil E, Cróquer A, Urreiztieta I. 2009. Yellow band disease compromises the reproductive output of the Caribbean reef-building coral Montastrea faveolata (Anthozoa, Scleractinia). Diseases Aquatic Organisms 87:45-55.

Williams GJ, Price NN, Ushijima, Aeby GS, Callahan S, Davy SK, Gove JM, Johnson MD, Knapp IS, Shore-Maggio A, Smith JE, Videau P,Work TM. 2014. Ocean warming and acidification have complex interactive effects on the dynamics of a marine fungal disease. Proceedings of Royal Society Biology 281:20133069 


\section{Figure 1 (on next page)}

Nursery line of the Gorgonia ventalina fragments with treatment enumerated. 

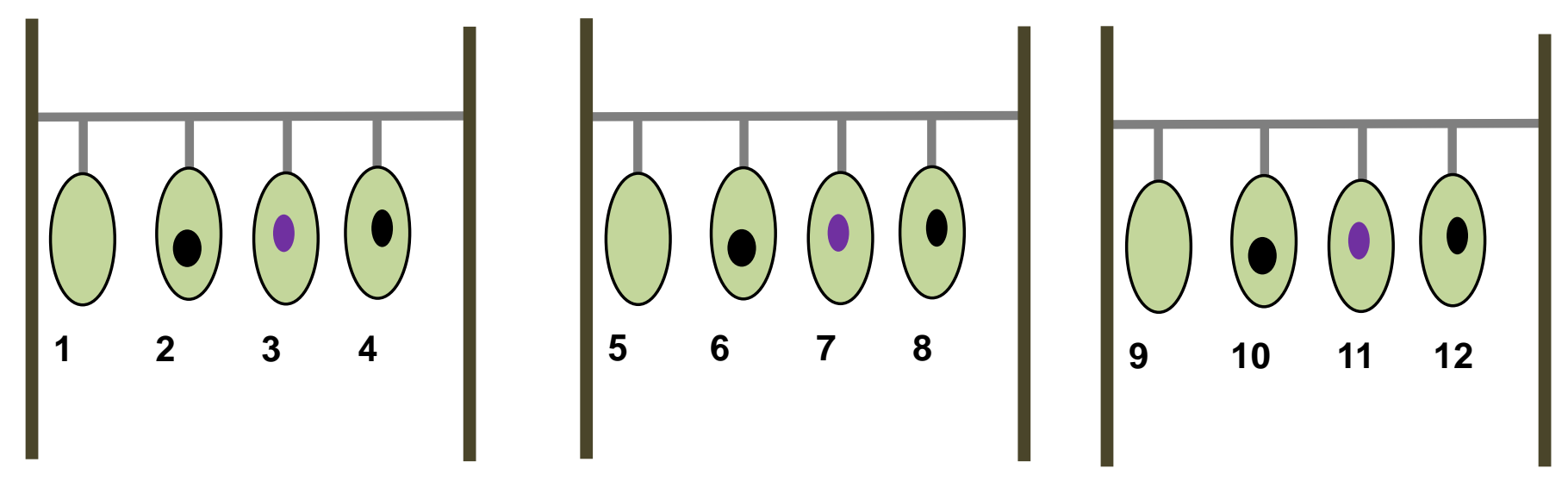

5 meters deep
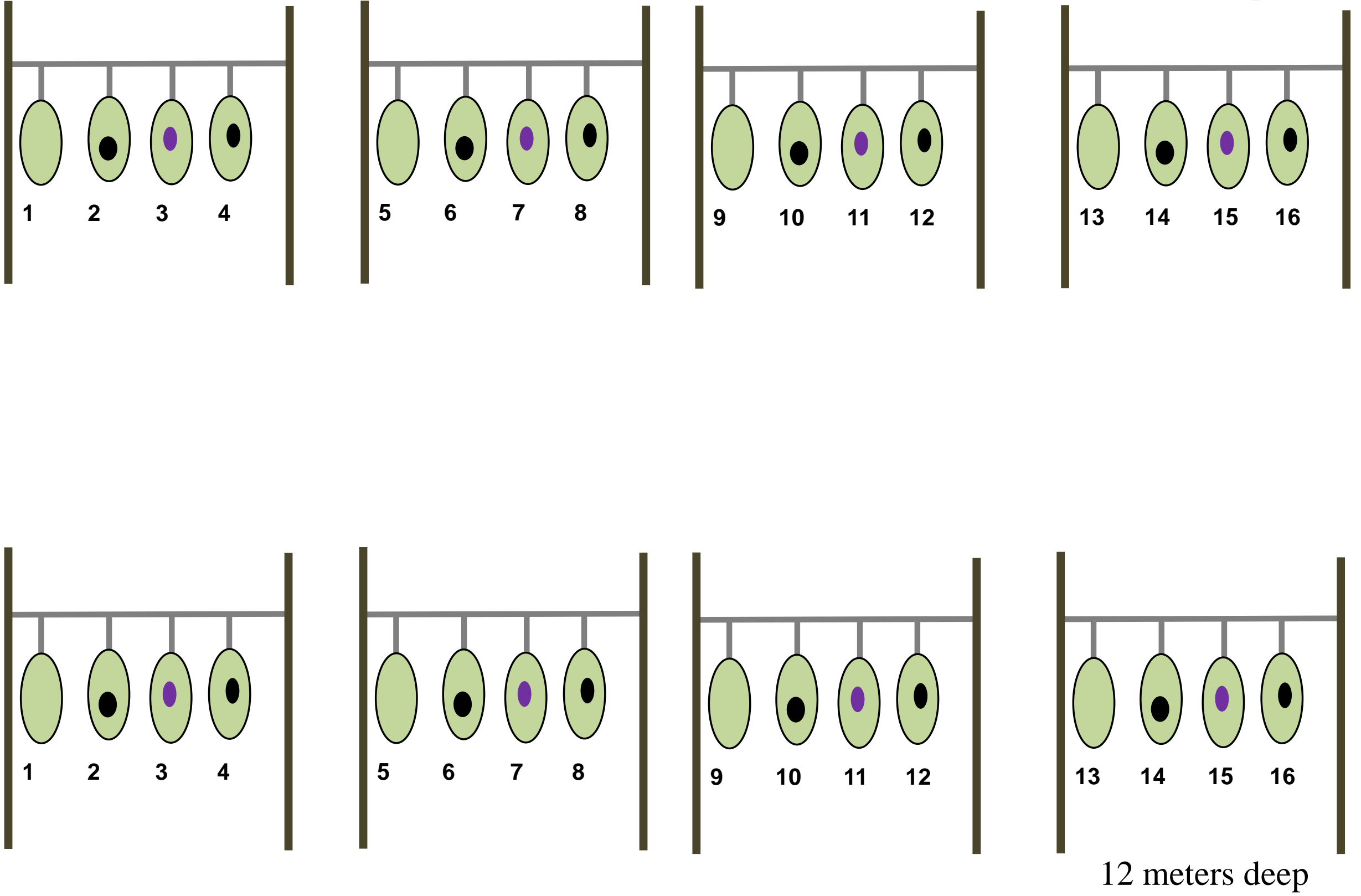
2

Example of wound-healing process.

Figure 2. Close-up pictures of scraped healthy individuals showing the healing process over the course of the experiment. 
April 26, 2013

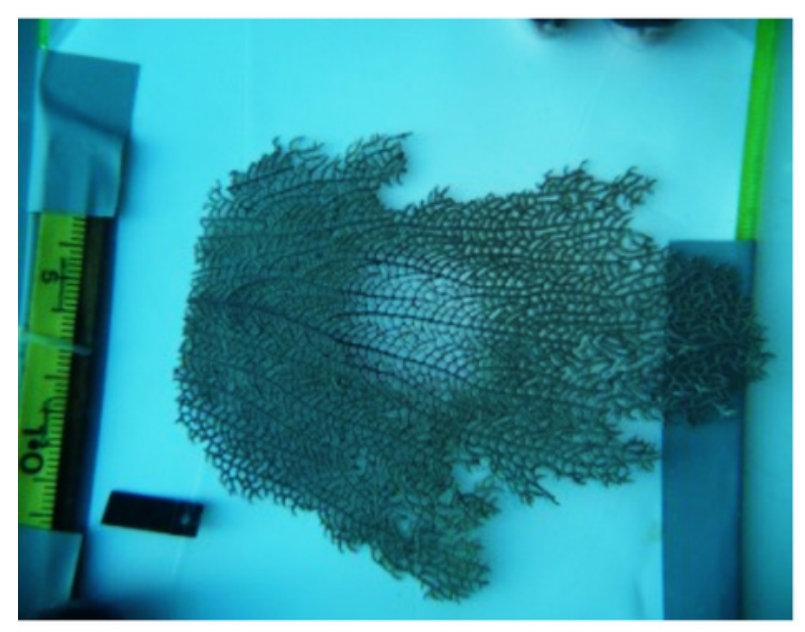

June 28, 2013

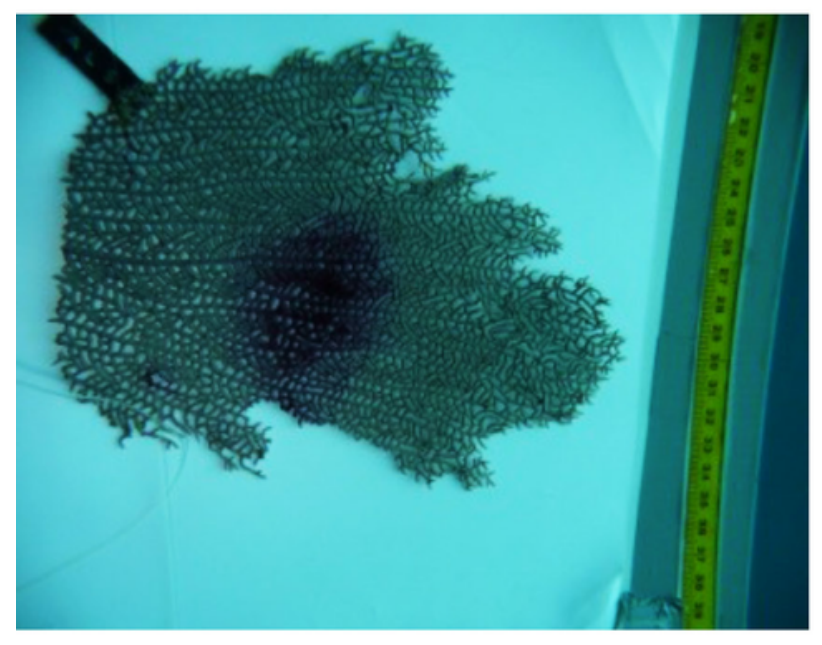

August 9, 2013

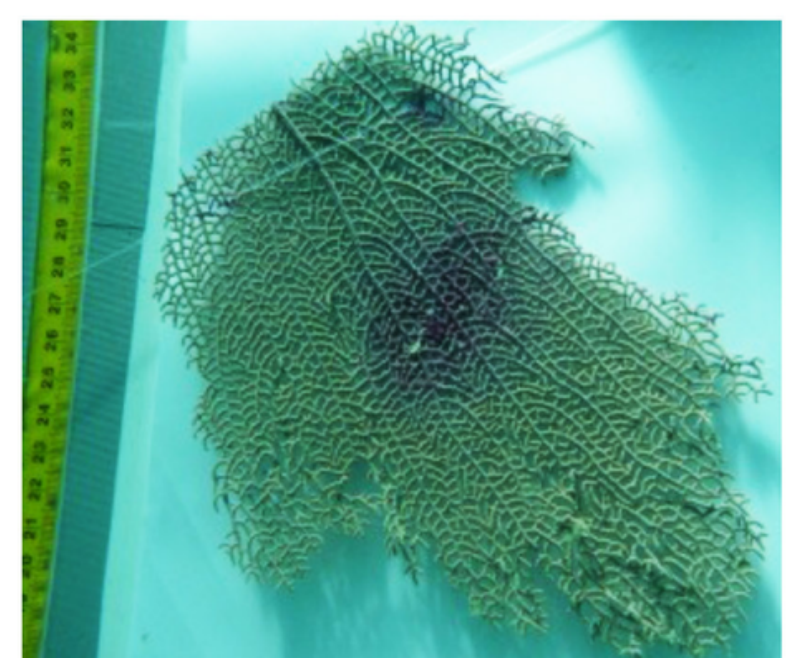

May 16, 2013

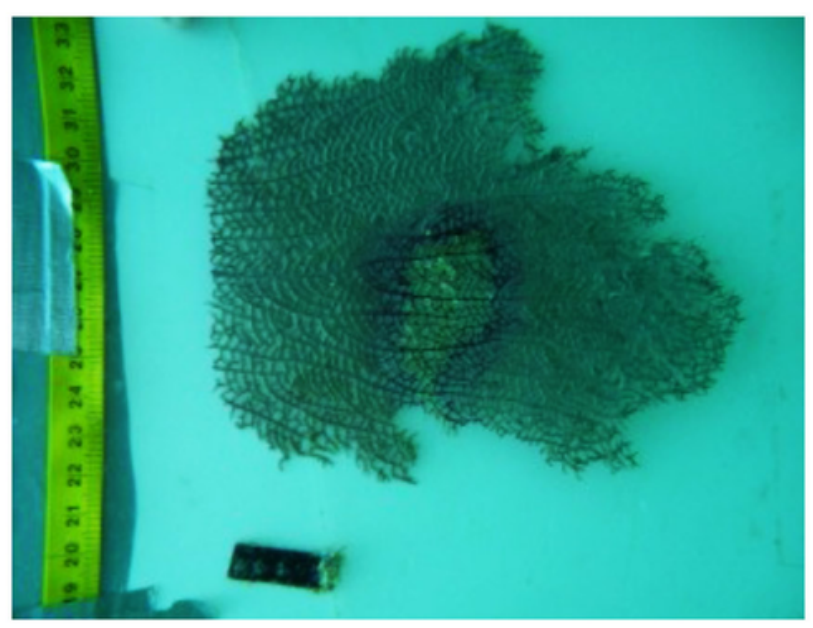

July 12, 2013

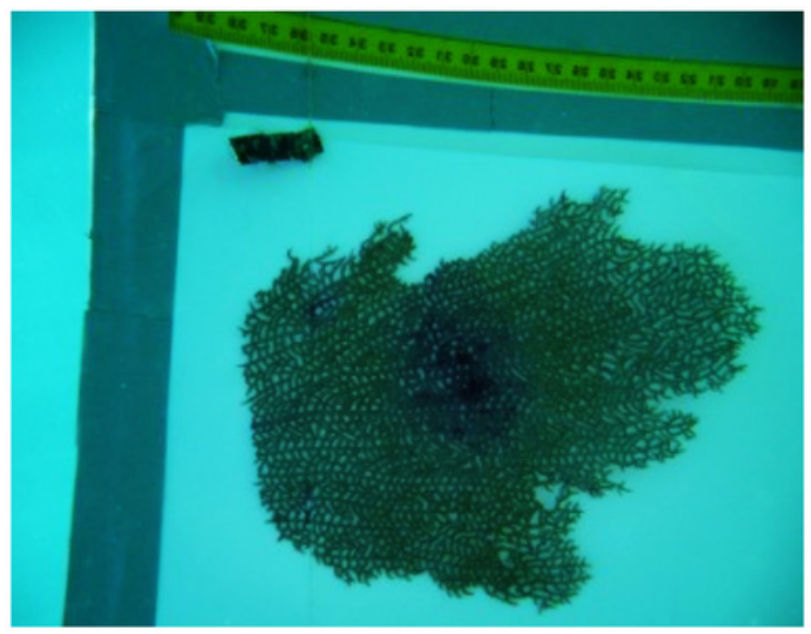

August 30, 2013

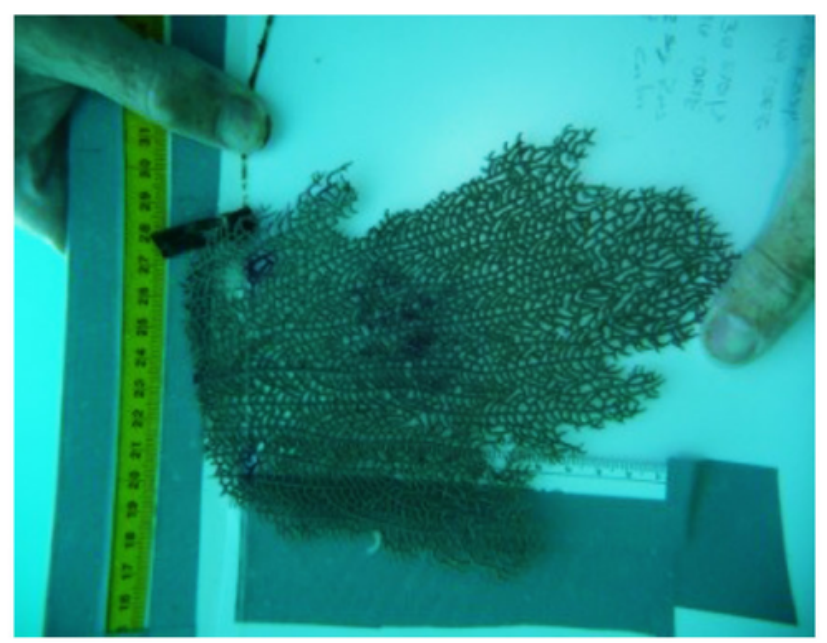




\section{Figure 3 (on next page)}

Boxplot showing the slopes (rate at which tissue regenerated) through time) between health state treatments (healthy and diseased) and fragments.

Figure 3. In the boxplot median is represented by the bold line, the extremes of the box are the $1^{\text {st }}$ and $3^{\text {rd }}$ quartile and the whiskers are the maximum and minimum. DF: diseased fragments, DFS: diseased fragments scrapped, HFS: healthy fragments. 


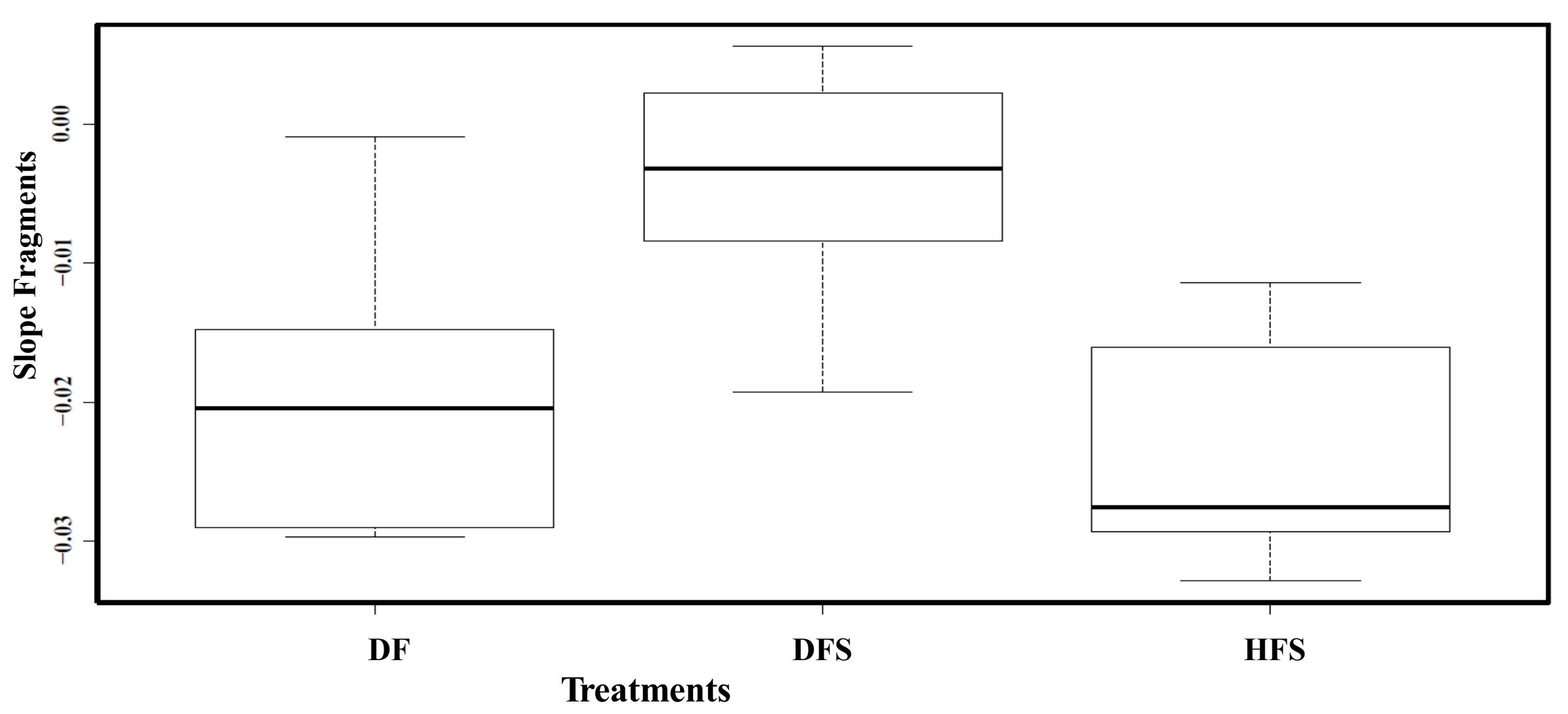




\section{Table $\mathbf{1}$ (on next page)}

t-test statistics for light intensity and temperature for different time periods for both the shallow and deep sites.

The experimental period lasted between April 26 to August 232014. 


\begin{tabular}{|l|c|c|c|c|}
\hline & April 26-May3 & May 16 - June 7 & June 28 - July 12 & August 9-August 23 \\
\hline \multirow{3}{*}{$\begin{array}{l}\text { Light } \\
\text { Intensity }\end{array}$} & $t=15.13$ & $t=15.52$ & $t=17.58$ & $t=17.53$ \\
\cline { 2 - 5 } & $d f=363.40$ & $d f=992.63$ & $d f=902.61$ & $d f=897.81$ \\
\cline { 2 - 5 } & $p<0.001$ & $p<0.001$ & $p<0.01$ & $p<0.001$ \\
\hline \multirow{3}{*}{ Temperature } & $t=10.42$ & $t=17.50$ & $t=12.87$ & $t=26.72$ \\
\cline { 2 - 5 } & $d f=838.22$ & $d f=3541.62$ & $d f=2274.34$ & $d f=3051.96$ \\
\cline { 2 - 5 } & $p<0.001$ & $p<0.001$ & $p<0.01$ & $p<0.001$ \\
\hline
\end{tabular}

1

2

3

4

5

6

7 